\title{
Constructing Student-Teacher Identities via a Mentorship Programme Initiative: A Case for School-Based Learning
}

\author{
Gregory Alexander \\ Department of Postgraduate Studies: Education \\ Faculty of Humanities, Central University of Technology \\ alexanderg@telkomsa.net \\ Micheal M van Wyk \\ Department of Curriculum and Instructional Studies \\ College of Education, University of South Africa \\ vwykmm@unisa.ac.za \\ Boitumelo B Moreeng \\ School of Social Science and Languages education \\ Faculty of Education, University of the Free State \\ Moreengbb@ufs.ac.za
}

\section{Doi:10.5901/mjss.2014.v5n9p405}

\begin{abstract}
The aim of this paper is to explore how student-teachers narratively constructed their identities through a mentorship schoolbased approach. These prospective teachers used typologies of their identities as a base of support for their becoming teacher professionals. This study employed a qualitative research method via semi-structured interviews and explored studentteachers' learning experiences during the school-based learning project. From these interviews, which are inductive in nature, we first sought out recurring themes in student-teachers' ways of speaking about their mentors and their experiences of the school-based learning project. The findings revealed that PGCE student-teachers' exposure to a structured mentorship programme provides more than adequate opportunities for the enhancement of personal growth and professional development; thus reinforcing the construction of multiple teacher identities.
\end{abstract}

Keywords: student teachers, identities, mentorship school-based project, narratives, interviews

\section{Introduction}

This paper explores how student-teachers identities, via a mentorship school-based project, were narratively constructed and understood as a means of creating typologies of their identities in becoming professionals. The interpretations of data gathered during this study, used a framework of social learning as a process for understanding identity development. Attending to identity development has been described as a crucial feature within initial teacher education programmes. Our contention is that the identities student-teachers develop, shape their dispositions; where they place their efforts; whether and how they seek out professional development opportunities, as in this case via a mentorship school-based project; and what obligations they see as intrinsic to their future role as professional agents advancing change in their respecitive communities. Student-teacher interviews were analysed within a theoretical framework based on poststructuralist and discourse theory, combined with theories of narrative identity (Mishler 1999; Weedon 1997; Beijaard, Verloop, and Vermunt 2000; Foucault 2002; Zembylas 2008). This combination of theories framed the research questions in a fruitful way, as it provides a theoretical base for analysing and understanding the construction of student-teacher identities as a narrative and discursive process within this school-based project. The theoretical framework also provides an analytical focus, as it presupposes an understanding of the subject and subjectivity, as produced in the discourse (Weedon, 1997; Wetherell et al., 2001). An understanding of the subject as discursively produced will shift the analytical focus from the individual student-teachers' identities to their narrative expressions about what it is like to be a future teacher and the narrative resources for identity construction. The focus will, in other words, be on the structures in which 
these student-teachers are embedded, such as their participation in the Post Graduate Certificate of Education (PGCE) programme during their school-based project. The research question, the theoretical approach and the analytical focus framing this article are therefore focused on illuminating the narrative resources, processes and identity constructions and not, per se, on the single, individual student teacher.

\section{Conceptualisation of Identity and Discourse Construction}

Dealing with the concept identity is not an easy task. The definition and conceptualisation thereof is vast and broad. For Danielewicz (2001), identity refers to our understanding of who we are and who we think other people are. This stance seems to be supported by Gee when defining identity as being a certain 'kind of person in a given context' (Gee 2000). In this case, identities are viewed as something claimed or assigned. From the two definitions, one can therefore deduce that identity construction is reliant on how the individual perceives him/herself and also how other people in particular contexts view an individual. There might therefore be clashes between the personally constructed identity and the one viewed by other people. The situation might worsen in cases where power relations are involved and the personally constructed identities have to suit the expectation of the powerful (Foucault 1984). Moreover, Jones (2008) seems to articulate this clearly by claiming that people are governed by social expectations which result in their positioning themselves according to the fields of operation. Trent and Decoursey (2011) concur with Jones by stating that identities are fashioned and refashioned within social contexts and conditions, which include social organisations, such as schools, and cultural products, including language and knowledge throughout the school-based mentorship project. This usually results in identities that are neither fixed, stable or permanent, but change according to the variety of cultural systems which present themselves; thus assuming different identities at different times (Hallman 2007; Jones 2008). We are therefore of the opinion that identity is viewed as something which is not already there but rather, as in process as is evident in this study. It is situational, as parts of a community of practice shift from context to context (Hallman 2007) and in particular, in this case study with the PGCE student-teachers. Notwithstanding, the identity-building process of new teachers and student-teachers will therefore be even more complex, as it might be influenced by the expectations lecturers hold of what is really expected of these prospective students upon entering the profession. Thus, when studentteachers in this case study do their placements as part of the school-based metorship initiative (teaching practice sessions), they take with them the identities they created for themselves which might be from their experiences gathered from their school days. These identities might be of their teachers and of their lecturers at university level to which they have been exposed. We are of the view that these experiences by student-teachers throughout the school-based mentorship initiative have been modified, confirmed or reconstructed when they attended schools during the mentorship programme. In this context, Wenger (1998) refers to identity formation in terms of the negotiation of meaning within a specific social setting. On the other hand, discourse also plays a significant role in the poststructuralist understanding of teacher identity. These student-teachers' identities were enhanced through their participation in school-based discourses. Moreover, Hallman (2007) concurs with the latter author and is of the opinion that the creation of one's identity is always connected with the use of discourses. Furthermore, discourses act as identity kits and come complete with the appropriate costume and instructions on how to act, talk, and often write; that is, to take a particular role which others will recognise. The concept of the identity of the post-modern subject is of particular relevance, especially in domains where various global and economic structures have shifted. This, as Jones (2008) argues, has destabilised the sense of self and has resulted in a fragmentation and crisis of one's identity. Creating an identity means employing a particular discourse which might involve exploring in a variety of ways. In locating identity construction within the post-structuralism paradigm, Trent and Decoursey (2011), as well Zembylas (2003) maintain that it seeks to understand how institutions and those working within them are affected and produced by wider idealogical discourses. In doing so, it facilitates an understanding of meaning making processes and connections between local and historical discourses. Scholars argue that discourses are not static and bounded but rather, fluid. Discourses are manifested through language, organised hierarchically, inherently idealogical in nature and are reflected in their constitution as beliefs, attitudes and values that exist within particular social and cultural practices (Somers and Gibson 1994; Beauchamp and Thomas 2009; Hallman 2007; Zembalas 2003; Trent and Decoursey 2011).

Beijaard, Verloop and Vermunt (2000) posit that teachers' discourses are constructed during dialogical spaces which impact on their daily practice. Trent and Decoursey (2011) concur with the concept of identity-in-discourse and further include the concept of identity-in-practice as another component of identity construction. Identity-in-practice is an action orientated approach in understanding identity and underlying the need to investigate identity formation as a social construct, which is operationalised through concrete practices and tasks. Beauchamp and Thomas (2009) therefore talk about the use of teachers' own narratives about themselves. In the process, the influence of contextual factors on 
teachers and their practice are acknowledged, resulting in multiple forms of identity. These myriad experiences and knowledge, to which student-teachers are exposed, will result in a shift in identity. As they move through teacher education programmes and further their careers via professional development activities, student- teachers constantly reinvent themselves in the learning process (Beauchamp and Thomas 2009). Preservice teachers therefore take on a variety of identities, depending on the context in which they find themselves; thereby they are able to respond to multiple audiences (Hallman 2007).

\section{Theoretical Construction of Identity}

We now draw on the social cognitive learning theory and the social capital theory as a basis for conceptualising the construction of teacher identity.

\subsection{Social cognitive learing theory}

It is important to be clear on the framework of reference that guides the mentorship programme initiative and at the same time, have a mutual understanding of important issues, such as learning and more specifically, the co-operativist learning relationship between mentor and student-teacher (not to be confused with co-operative learning as a teaching approach). There is broad consensus on what learning is all about. De Corte and Weinert (2004) view learning as a constructive, cumulative, self-regulated, goal-directed, situated, collaborative and individually different process of meaning construction and knowledge building.

Although all of the above characteristics of learning are important in the learning process between mentor and student-teacher, it is necessary to highlight three aspects that will play an important role in the mentorship programme. In the first place, learning will be contextualised (situated) in the sense that student-teachers will be placed at schools and will thus be exposed to real-life situations in the education profession. Secondly, learning in this mentorship programme should be collaborative. It is generally agreed that a social learning environment, where the student-teacher interacts with others (peers, mentors, teachers and lecturers) is more conducive to learning; this is in keeping with Bandura's point of view that learning is a social activity (Bandura 1986; Alexander 2005). The potential of the learner (student-teacher) will materialise if he/she interacts with more knowledgeable people, such as mentors and senior teachers. What studentteachers learn from interacting with their mentor and peers will be coined as 'acquired knowledge' which may be applied to other teaching situations. Therefore, it will be a challenge to mentors to plan and manage successful co-operative learning opportunities for their respective student teachers. According to Bitzer (2001) and van Wyk (2007), co-operative learning is enhanced by the following teaching principles:

- Positive interdependence. It is important that the mentor constructs an environment in which everyone believes that they need one another.

- Individual accountability. The student-teachers should realise that their contributions are essential for their own success and that of the programme (including mentors and teachers).

- Promotive interaction by means of face-to-face sessions. Mentors and student-teachers need to interact with one another, encourage one another and work together. Mentors need to maximise student-teachers' participation within the given constraints. Feedback sessions are important where, inter alia, hard work is encouraged, enthusiasm is demonstrated and challenging ideas are exchanged and developed.

- Interpersonal and small-group skills need to be developed.

- Group processing skills should be encouraged, where student-teachers can think, talk and reflect on their academic and social skills that will contribute to their learning.

Thirdly, the purpose of this mentorship programme allows student-teachers to build subject and pedagogical content knowledge and construct meaning from the day-to-day aspects confined to the teaching profession. It is the task of the mentors to facilitate the learning process for the student-teachers in such a way that student-teachers are supported in constructing their own knowledge of a teacher identity.

\subsection{Social capital theory}

Several scholars indicate social capital as a phenomenon which is understood as the 'good-will' that is engendered by the fabric of social relations and that can be mobilised to facilitate action amongst schooling and education, community life, democracy and governance, economic development, and general problems of collective action (Jackman and Miller 
1998). Other scholars aver that social capital influences career success (Burt 1998; Gabbay and Zuckerman 1998). On the other hand, Coleman (1990) defines social capital as a function to enhance human beings' capabilities, which per se, should not be viewed as a single entity, but as a variety of different entities having two common characteristics. These constructs are the social structure in which individuals operate, and the manner in which specific actions of individuals are facilitated within this structure. Moreover, Fukuyama (1997) views people's ability to work together for common purposes in groups and organizations as an important fibre in the social structure in which they operate. He furthermore defines social capital as the existence of a certain set of informal values or norms shared among members of a group that permit cooperation among them. In this study, the Post Graduate Certificate of Education student-teachers are involved in a school-based learning project to enhance their subject content knowledge (SCK) and pedagogical content knowledge (PCK) and as such, construct meaning from their daily classroom experiences and interactions.

\section{Work Integrated Learning as a Teacher Development Imperative}

The transformation of education in South Africa led to a change in how teachers were trained. Prior to 1994, there were 101 public colleges and 22 universities in South Africa offering initial teaching qualifications (Pratt 2001), which were informed mainly by the divide-and-rule apartheid policy. After 1994 (the first democratic elections), there were several attempts by the Department of Education to revamp teacher training. Some of the colleges of education were amalgated with, or incorporated into existing faculties of education at university level, whilst some colleges were closed. Some of the post-apartheid policies that inform teacher training and professional development in South Africa include the Norms and Standards for Educators (DoBE 2003) and the Higher Education Qualification Framework (DoHET 2007). These documents all identify and outline the different types of learning and competencies needed to develop a teacher for a diverse South Africa. Furthermore, the South African initial teacher training context necessitated that student- teachers needed to be exposed to the acquisition, integration and application of knowledge; this process required various types of learning, such as disciplinary, pedagogical, practical, fundamental and situational learning.

This paper focuses on one form of learning, the practical learning component and how it impacts on the construction of the professional identity of student-teachers via a school-based mentorship project. Practical learning involves learning from practice through an analysis of different practices, such as case studies, video records, and lesson observations as was the case with this project. On the other hand, learning-in-practice refers to work-intergrated learning (WIL) which occurs in workplace settings and is aimed at preparing, teaching and reflecting on one's practice (DoHET 2007). Emphasis in the next paragraph is on how work-integrated learning is employed through the use of a mentorship programme as a means of constructing professional teacher identity.

\section{Mentorship Project as a School Based Learning Initiative}

In South Africa a professional teaching qualification can be accessed through a four-year Bachelor of Education (B Ed) programme or a one-year full-time, or two-year part-time Post Graduate Certificate in Education (PGCE) programme. PGCE students have already completed a degree in another field besides education. This necessitates an investigation into how students navigate the expectations of the teaching profession, and how the knowledge they have gained from their initial studies, impacts on the new professional identities they have to create. In addition to the other practice teaching related activities, such as experimental lessons, micro teaching sessions and the six-week visits to a school, the PGCE group also has to participate in a mentorship programme for an additional six weeks. The mentorship programme is informed by the principle of cognitive apprenticeship. At first, the mentor is very actively involved and the studentteacher is more of an observer. In due course, the mentor moves to the background and the responsibilities are passed onto the student teacher. During work-based learning activities, student teachers are allocated specialist mentors with whom they are actively involved. To assess progress and related challenges, student-teachers and mentors are visited on regular basis by the lecturers from UFS. Student-teachers should be actively involved in the training model and constantly reflect on their practice. Reflection should occur at regular intervals, preferably after the facilitation of lessons and a whole-school approach encouraged. This results in the student -teacher being exposed to as many aspects of teaching as a profession, as possible. During this time, student-teachers are placed in schools for eight weeks, and assigned a guardian and mentor teacher. The role of the guardian and mentor teacher is to expose the student teacher to all facets of the teaching profession. These will range from planning, administration and extra-mural activities to dealing with parents, the community and labour relations issues (Van der Merwe, Van Wyk and Van Wyk 2009). This approach will require a reflexive method from the student-teachers, as it will allow them to revisit the processes involved in producing the kind of identity needed for the profession; thus, they will be able to evaluate and build on their experiences. 
Furthermore, a reflexive approach will further allow student-teachers to engage critically with the knowledge base of their subject, thus positioning themselves as knowers of their subject and drawing on, and challenging their experiences, values and identities (Burke 2002). It enables student-teachers and mentors to identify problems, deliberate, propose solutions and respond to contextual changes in an ongoing series of action and reflection cycles.

Next, we discuss our methodological considerations for conducting this study.

\section{Methodological Considerations}

\subsection{Research design and data cgathering instrument}

Recent research studies in teacher education show a growing interest in using the case study as a research method. This study employed a qualitative research approach via the use of semi-structured interviews to explore student-teachers' learning experiences during the school-based learning project. This was undertaken in order to gain a richer and deeper understanding of views of student teachers on becoming professionals through narratives (Bathmaker and Harnett 2010; Søreide 2006). We therefore utilise narratives and open-ended responses, because they assisted us in understanding patterns in student-teachers' experiences during their school-based learning visits. Linde (1993) coined these stories, as culturally defined landmarks of people's lives which are repeated over time and across various occasions. The narratives and open-ended responses of student teachers are 'primary evaluative points of departure'; a moral evaluation about the speaker(s) as person. Moreover, Mishler (1999) states that the student-teachers' responses about their lives and experiences are used to identify performance. We believe that the way in which student-teachers tell, express, display and make claims about themselves in these narratives, are significant.

\subsection{Selection of participants, data generation and collection procedure}

This study was conducted in the Faculty of Education, at an institution of higher learning. This project was a partnership between the Faculty of Education, the Free State Department of Education (FSDoE) and participating high schools in the Motheo education district of the Free State province. After consultation with the departmental learning facilitators (Subject advisors), a number of participating schools were selected and principals were involved in the selection of experienced mentor teachers. These school-based mentors were trained at the faculty. Sixty-eight ( $N=68)$ PGCE students were each allocated to a trained mentor teacher, on a one-on-one basis, for a continuous period of a quarter (third quarter) during July-September 2013. The PGCE students had to become totally involved in the day-to-day activities of the school, including: facilitation, assessment and administrative aspects, as well as extra-mural activities. The student-teachers and mentors were visited by lecturers at their schools at regular intervals and had to share positive and negative aspects of their experiences. Student-teachers had to keep a logbook or diary and compile a portfolio of evidence of all the relevant aspects during the term of the school-based learning period. Personal reflection, as well as mutual reflection between student-teachers and mentors at different stages formed an integral part of the project. Visiting lecturers also had to document their observations (observational notes) during school visits. Only six students responded to our official invitation. In the end, we decided to purposefully select four students from the list. Firstly, we chose a diverse student group for our quota sampling. Secondly, a quota sampling was based on identity, social class and learning experiences for the purpose of the study. Lastly, the selected students were willing to participate after we had explained the purpose of conducting the research. Semi-structured interviews were conducted with student-teachers (Franzak 2002; Clandinin and Connelly 2000). The interviews were conducted in places where they felt comfortable and where they attended many classes. The interviews, each lasting from 1 to 2 hours, covered how they see the role of a teacher and their experiences during the mentorship programme initiative. The interviews were first transcribed in detail and saved as an original version. To make the student-teachers' narratives more visible and readable, the transcribed interviews were then rewritten as condensed and coherent stories. To ensure that there were no major changes to the content of the refined student-teachers' narratives, they were compared with the original transcript and the tapes from the interviews. The student-teachers' narratives were then organised thematically before they were analysed in a five-phase process.

\subsection{Data analysis and ethical considerations}

Student-teachers' narratives are both inductive and deductive in nature. These interviews were inductive, in that we first sought out recurring themes in student-teachers' ways of speaking about their mentors and their experiences of the school-based learning project. Additionally, the data analysis was deductive, in that we searched for themes that we 
expected to be present in their voices from their personal experiences of the school-based learning project. Before we could begin with the study, we obtained consent from the student-teachers. We explained the purpose of the study to the participants. We decided beforehand to use pseudonyms for the names of the students who participated in this study. We then explained the purpose of confidentiality to the student teachers.

Next, we analysed the narratives the PGCE student-teachers told which highlighted their school-based learning experiences.

As the PGCE student-teachers position themselves in different ways with the help of the subject mentors, they simultaneously construct different possible teacher identities. In the analysis of the five interviews, four major constructions of teacher identity emerged:

- $\quad$ the caring and kind teacher;

- $\quad$ the creative and innovative teacher;

- $\quad$ the professional teacher; and

- the typical teacher.

These identity constructions are not to be understood as ready-made and sharply defined identities but rather, as more flexible 'clusters' which are constructed by the subject positions the student teachers related to in the interviews.

\section{Findings and Discussion: Narratives of Student-Teachers}

\subsection{The caring and kind student teacher in becoming a professional}

Research studies have been shown that caring has been conceptualised as a highly gendered construct and is set in opposition to paid work, training and professionalism (Griffin 1997; Rogers and Webb 1991; Søreide 2006; Watson 2007). It is, in our view therefore, crucial when seeking to reclaim caring as an activity of value and necessity and not to perpetuate the discourse of femininity and gender difference. We therefore contend that caring is widely believed to be a central facet of the teaching profession. Kohl (1984) asserts teachers' obligation to care about their students while Rogers and Webb (1991) insist on and support the latter by postulating that 'good teachers care, and good teaching is inextricably linked to specific acts of caring'. Furthermore, research into the subjective views of teachers has highlighted the importance of personal investment, commitment and relationships for teachers' work, motivation and satisfaction; primary teaching has been conceptualised as a 'culture of care' (Nias 1998). Moreover, Nias (1999) distinguishes crucial aspects in relation to the culture of care in primary teaching as affectivity; as responsibility for learners; as responsibility for the relationships in the school; as self-sacrifice; as over-conscientiousness; and as identity. It is evident from this study that identity is a powerful resource for student-teachers when they present themselves as caring individuals during the school-based mentorship project. Some of the PGCE student teachers explicitly describe themselves as exceptionally kind and caring persons, such as Jessica (Mathematics education):

You could say that I don't like to be stricter than I have to. But the caring and kind teacher is a teacher who first of all feels close to the pupils and cares for them.' ' think it is great to be with the pupils' Alice says when she is asked about why she is still a teacher. And she goes on to say: 'I really care for the pupils in my class and it is so nice to teach them'.

Søreide (2006) maintains that the emotional aspect involved between teacher and children seems to be crucial in forming healthy opportunities for bonding in the class. In this case, prospective primary school student-teachers, more so than high school student teachers, give reasons related to caring as a motivation for becoming a teacher. Moreover, Acker (1995), as well as Hubbard and Datnow (2000) are of the opinion that the importance given to caring in teaching might be related to gender and in particular, to women teachers who have been found to be more strongly involved in aspects which relate to the caring role of teaching.

Marlé, a Life Orientation student teacher even describes her grade 8 learners as:

'Hulle het in my hart gekruip' [They have been climbed into my heart]. " $n$ Mens raak baie lief vir hulle hulle is oulike kinders' [One gets to love them - they are cute children].

This student-teacher demonstrates her care, love and compassion by building a good relationship with these learners whom she taught during the teaching practice sessions. Another important component of emotional relation to the learners seems to be a feeling of responsibility for the children's well-being and development. Grethe (Business Studies) puts it this way: 
Truly speaking, I love to work with learners, which is my motivation and passion. The best thing is to be in contact with the kids and, so to speak, help them to develop their abilities; to see them apply their acquired knowledge and skills and to develop positive attitudes to schooling. I love to see how they felt good about themselves. If they achieved good results in their subjects, they are happy learners who enjoy themselves. These learners became part of your life. They are like family.

Grethe continuously uses this identity construction as a resource in her description of what she considers positive milestones in creating a teacher identity. Other identity constructions are patience and a sense of humour, which are important because they will assist the teacher to get on well with the learners. The following question was asked: What is the most important thing you do as a student-teacher in your current Language class? Grethe said:

'I have good communication with them and a lot of humour. Yes, and they must feel safe when they sit there. If you have insecure learners who are afraid of the teacher, they don't work very well'.

We argue that student-teachers who care want their learners to enjoy learning. Caring means going to great lengths to create lesson plans, learn individual styles, and attempt to make provision for learners' diversity. We further contend that a caring teacher is one who cares about the children's personal life and interests. In acknowledging caring as an important aspect of teachers' professional identity, caring should not be defined as an exclusively motherly or parental activity. Defining a caring teacher as committed to teaching and to professional relationships with the learners, would allow one to value this very important aspect of teaching, without perpetuating patriarchal discourses which link caring to femininity. We are of the opinion that a caring and compassionate teacher should be available to the child in any capacity and should never turn a deaf ear on a child's problem or concern. He or she should also help the child in meeting his or her potential in all areas of school and should further assist him/her to understand his/her personal interests. In our view, a caring teacher should be quick to praise and never ridicule a learner in front of others. We conclude that all of our student-teachers believe caring to be an important part of their teaching lives and identitiesThe idealistic, romantic and beliefs student teachers hold about the relationship between teaching and caring acts as a powerful starting point for a productive and educative dialogue in their role as prospective teachers. Student teachers need to build on this knowledge to become true teaching professionals.

\subsection{The creative and innovative teacher}

Many research studies have evidenced the influence of personalities and developments of creativity on teacher identity. The common personality traits of subjects are: self-confidence; openness to experience; fantasy oriented; imagination; emotionally sensitive; drive and ambition; norm doubting (questioning established norms); nonconformity; attraction to complexity; aesthetic orientation; flexibility of thoughts and risk taking (Wang and Cheng 2000; Strom and Strom 2002). Creative teachers are more oriented towards 'new' ideas about schooling and teaching. The importance of the concept of professional identity lies in its relationship to professional knowledge and action, but these links are complex (Watson 2007). The interviewees showed their perseverance in dealing with difficulties, a desire to learn and absorb new experiences, self-confidence, and strong aspirations to acquire new knowledge. By participating in the school-based mentorship project, these student-teachers constantly absorbed new information, reinforcing their professionalism and investing more creativity in class activities for learners. For example, Maleke (Economics student-teacher) expresses a creative and flexible attitude when he says:

I introduced social media in my teaching. For example, I started a blogging page where my grade 10 learners participated in. I am creating new learning opportunites in my classes. You have to see the opportunities at all times, and don't lock yourself up and think 'This is not possible', but rather, 'what can we do to make this work?' We are the next generation, so why not accommodate my diverse learners?

Furthermore, Maleke alluded to the shared experiences of developing new ideas, designing applicable curricula, arranging effective classroom activities, revising teaching plans, preparing materials and reflecting on his performance and the learners' assignment feedback. In this study, student-teachers demonstrated that thinking is a process of combining information and creativity. During the school-based metorship programme it was found that the analyses of subject lesson plans, the implementation of learning activities in a creative way, were impressive. Several scholars concur that a teacher within this identity construction is also eager and willing to learn more and develop his or her own competencies, in addition to the continuous development of teaching skills and methods (Muwanga-Zake 2010; Søreide 
2006). A response from student-teacher, Veronica (African Language) indicated that creative and innovative attitudes have a connection to her own competencies:

'I really feel that I can use my strengths' she says and points to another aspect within this identity construction. 'There are so many challenges every day. And although sometimes it's too much [laughs] I like some action. I'm not the kind of person who can sit in an office and, for example, work with numbers. That would drive me crazy'.

We contend that in comparison to traditional cramming education methods, creative instruction encourages student-teachers to think independently, participate actively and express themselves freely. We believe that studentteachers, in attemting to be creative in their teaching, are more likely to become creative professionals if an enabling environment is created by mentor teachers and school principals; student-teachers need to be provided with ample 'space' to grow as professionals.

Lastly, we conclude that strategies to enhance creative instructions for teacher professional development could include aspects, such as student-centred activities; multimedia assistance; classroom management; the connection of teaching contents to real-life situations; open-ended questions; and encouragement to think creatively.

\subsection{The professional teacher}

Scholars of teacher professional development opine that working hours, responsibilities as a teacher and what it is like to be a teacher in the local community have a great influence on teacher identity per se (Watson 2007; Hargreaves 2000). The phrase 'professional' is used by in-service teachers who focus on their private lives and working hours. We agree that although teachers are generally required to take part in professional development by certification or contractual agreements, most report that they engage in these activities because they want to become better teachers. Fullen (1991) views professional development programmes as among the most promising and most readily available routes to growth on the job. Huberman (1995) contends that in-service professional development is not only a way to combat boredom and alienation, but also serves as a pathway to increased competence and greater professional satisfaction. In this study, student-teachers indicated that they were intrinsically motivated because they perceive the activity of teaching as interesting, involving, satisfying, and enjoyable; a personal challenge towards excellence in the profession. What attracts teachers to professional development, therefore, is their belief that it will expand their knowledge and skills, contribute to their growth and enhance their effectiveness with learners. This said, teachers also tend to be pragmatic, that is, what they hope to gain through professional development is specific, concrete, and practical ideas that directly relate to the day-to-day operation of their classrooms. With reference to student teachers, Sandra and Jason (both Science students) expressed an explicit identification with this identity construction when they say:

We felt like a qualified teacher sitting in a staff meeting where we were introduced to provincial circulars dealing with staff matters (sick leave, workloads, November exams etc). Teachers in our subject meetings always referred to working hours and the responsibilities of the teaching job. We appreciated the farewell party that the teachers organised for the group of us. You felt that you are a professional.

We conclude that it is not the professional development per se, but the experience of successful implementation initiatives that change student-teachers, as well as those in-service teachers' attitudes and beliefs about the teaching profession. Most of these teachers believe it works because they have seen it work in practice, and that experience shapes their attitudes and beliefs in becoming a professional. Attitudes and beliefs about teaching in general are also largely derived from classroom experience. Teachers who have been consistently unsuccessful in helping learners from educationally disadvantaged backgrounds to attain a high standard of learning, for example, are likely to believe that these learners are incapable of academic excellence. If, however, these teachers try a new instructional strategy and succeed in supporting such learners' learning, their beliefs are likely to change. Again, the point is that evidence of improvement or positive change in the learning outcomes of school learners generally precedes and may be a prerequisite to significant change in the attitudes and beliefs of most student teachers and teachers alike. In this case, we argue that if a new PGCE teacher development programme or innovation is to be implemented, it should be a natural part of teachers' repertoire of teaching skills. Especially for programme continuation and expansion, student-teachers should come to use the new practices almost out of habit. If this is to occur, continued follow-up and support are essential for strengthening teacher identity. 


\title{
7.4 The typical traditional teacher
}

According to Søreide (2006) and Hubbard and Datnow (2000) the 'typical teacher identity construction' is the one most teachers refer to in an implicit way, with fewer explicit references to the relevant subject positions within this identity construction than in others. However, the interviews with student-teachers, highlighted the image of a traditional teacher who is a very responsible, structured person going about his/her daily tasks in a rigid manner. This identity construction positions the teacher as strict and demanding. Student-teacher, Ratsoane (Accounting education) sees teacher identity construction as follows:

\begin{abstract}
Yeah, a typical teacher! People expect some sort of strict, demanding perfectionist. I knew such a teacher especially in Accounting; you cannot make mistakes, then you are in trouble... you shouldn't have done this and don't do that .... I think people expect that, but maybe it's not like that at all. In addition, 'the typical teacher' does things the way he/she always has done them and he/she is, therefore, not very interested in changes in school and his/her own teaching.
\end{abstract}

\section{Conclusion}

A major research finding revealed that PGCE students' exposure to a structured mentorship programme provides more than adequate opportunities for the enhancement of personal growth and professional development, thus reinforcing the construction of multiple teacher identities toward professionalism. Findings further reveal that flexibility in studentteachers' narratives toward teacher identity construction is enhanced and how these identities are constantly shaped, reshaped and adapted to the situation through a process of personal growth and professionalism. It is further evident that they see themselves as: caring, kind, creative, innovative, typical traditional and professional in becoming teachers for the profession. Emanating from the latter, student-teachers in this study obviously used different narrative options and clearly edited their narratives according to how they wished to present themselves during the school-based mentorship project. The discussion of examples from the student-teacher narratives illuminates how different identity constructions are dependent on one another. It also shows how the construction of multiple identities and negotiation between them are a necessary part of the construction of a specific student-teacher identity toward attaining professionalism.

\section{Further Research}

The present study should be viewed cautiously because of limitations. The first limitation concerns the sample size which involved a small number of student-teachers $(n=68)$ who participated in this study. Because of the restricted range of participants, in future research studies, the researchers should include a more diverse and representative sample of teachers and principals. The second limitation is the time factor of this case study. This study was conducted over only a short time. A longer investigation period might yield different results. To obtain an additional understanding of the construction of student-teacher identity, it is however necessary to broaden the analytical focus to include the dominant discourses about teaching that operate in society. The findings of this study indicate specific issues relating to studentteacher identity construction and in particular, the following issues should be interrogated beyond the scope of the study presented in this article: How do dominant discourses about teaching, such as, accountability and professionalism, regulate teachers' access to the narrative resources? How are the subject positions and identity constructions informed by these and other discourses? How are the discourses informed by the subject positions and identity constructions of student-teachers? Although a broader focus will probably increase the complexity of our understanding of teacher identity, it will also hopefully move our understanding of student teachers and teacher identity beyond the most obvious cultural and gendered stereotypes.

\section{References}

Alexander, G. (2005). The Design and Evaluation of a Staff Development Programme for Amalgamated Schools in the Northern Cape. Ph.D. Thesis, Unpublished. Bloemfontein: University of the Free State.

Acker, S. (1995). Carry on caring: The work of women teachers. British Journal of Sociology of Education, 16(1), 21-36.

Bandura, A. (1986). Social foundations of thought and action: A social cognitive theory. Englewood Cliffs, NJ: Prentice Hall.

Bathmaker,A., \& Harnett, P. (2010). Exploring Learning, Identity and Power through Life History and Narrative research. Routledge, Taylor \& Francis Group: London.

Beauchamp, C., \& Thomas, L. (2009). Preparing Prospective Teachers for a Context of Change. Reconsidering the Role of Teacher Education in the Development of Identity. Cambridge Journal of Education, 39(2): 175 - 189.

Beijaard, D., Verloop, N., \& Vermunt, J.D. (2000). Teachers' perceptions of professional identity: An exploratory study from a personal knowledge 
perspective. Teaching and Teacher Education, 16, 749-764.

Bitzer, E.M. (2001). Understanding Co-Operative Learning: A Case Study in Tracing Relationships to Social Constructivism And South African Socio-Economical Thought. South African Journal of Higher Education, 15(2): 98-104.

Burke, W. (2002). Organization change: Theory and practice, Sage: Thousand Oaks.

Burt, R.S. (1998). "The Gender of Social Capital "Rationality and Society, 10:5-46.

Clandinin, D. J., \& Connelly, F. M. (2000). Narrative inquiry: Experience and story in qualitative research. San Francisco, CA: Jossey-Bass.

Coleman, J.S. (1988). Social capital in the creation of human capital. American Journal of Sociology, 94(Supplement): S95-S120.

Coleman, J. S. (1990). Foundations of social theory. Cambridge, MA: Harvard University Press.

Danielewicz, J. (2001). Teaching Selves: Identity, Pedagogy and Teacher Education. Albany, NY: State University of New York.

De Corte, E. \& Weinert, F.E. (2004). Instructional Psychology: Past, Present and Future Trends. Elsevier Publishers: Oxford: London.

Department of Education (DoE).(2000). Norms and Standards for Educators. Pretoria: Department of Education.

Department of Higher Education (DoHE).(2011). Policy on the Minimum Requirements for Teacher Education Qualifications. Pretoria. Government Press.

Department of Higher Education and Training (DoHET). (2007). National Policy Framework for Teacher Education and Development in South Africa. Pretoria: Government Press.

Department of Basic Education (DoBE). (2003). National Strategy for Further Education and Training: Policy. Pretoria: Government Press.

Foucault, M. (1984). Space, Knowlegde and Power. In Paul Rabinow (Ed). The Faucault Reader. New York: Pantheon, 239 -256.

Foucault, M. (2002). The order of things. London:Routledge.

Franzak, J.K. (2002). Developing a Teacher Identity: The impact of Critical Friends Practice on the Student Teacher. English Education, 34(4): 258-280.

Fullan, M.G. (1991).The New Meaning of Educational Change. New York: Teachers College Press.

Fukuyama, F. (1995). Trust: The social virtues and the creation of prosperity. New York: Free Press.

Fukuyama, F. (1997). Social capital and the modern capitalist economy:Creating a high trust workplace. Stern Business Magazine, 4(1).

Gabbay,S.M., \& Zuckerman, E. W. (1998). Social capital and opportunity in corporate R\&D: The contingent effect of contact density on mobility expectations. Social Science Research, 27: 189-217.

Gee, J.P. (2000). Identity as an analytical lens for research in education. Review of Research in Education. 25, 99 - 125.

Griffin, G. (1997). Teaching as a gendered experience, Journal of Teacher Education, 48:7-18.

Hallman, H.L. 2007. Negotiating Teacher Identity: Exploring the use of electronic teaching portfolios with

Preservice English teachers. Journal of Adolescent \& Adult Literacy. 50 (6) $474-485$.

Hargreaves, A. (2000). Mixed emotions: teachers' perceptions of their interactions with students. Teaching and Teacher Education, 16: 811-826.

Hubbard, L. \& Datnow, A. (2000). A Gendered Look At Educational Reform, Gender And Education, 12: 115- 129.

Huberman, M. (1995). Professional careers and professional development: some intersections, in: T. R. Guskey \&

M. Huberman (Eds) Professional Development in Education: new paradigms and practices (pp. 193-224 New York: Harper and Row.

Jackman, R.W. \& Ross, A.M (1998). Social Capital. and Politics. Annual Review of Politics, 1(1):47-73.

Jones, D. (2008). Constructing identities: Perceptions and experiences of male primary headteachers. In Early Child Development and Care.178 (7): $689-702$

Kohl, H. (1984). Growing minds. New York: Harper and Row.

Linde, C. (1993). Life stories: The creation of coherence. New York: Oxford University Press.

Mishler, E. (1999). Storylines: Craftartists' narratives of identity. Cambridge: Harvard University Press.

Nias, J. (1989) Primary Teachers Talking. A Study of Teaching as Work. London: Routledge.

Nias, J. (1999) Primary teaching as a culture of care, in: J. Prosser (Ed.) School Culture. London: Paul Chapman.

Pratt, E.(2001). Remodelling Teacher Education: A perspective on the cessation of college-based teacher education. Commissioned paper. www.chet.org.za/papers.asp

Rogers, D. L., \& Webb, J. (1991). The ethic of caring in teacher education. Journal of Teacher Education, 42(3): 173-181.

Somers, M., \& Gibson, G. (1994). Reclaiming the epistemological 'other': narrative and the social construction of Identity. In: C. Calhoun (Ed.) Social theory and the politics of identity .Oxford, UK: Blackwell.

Søreide, G. E. 2006. "Narrative Construction of Teacher Identity: Positioning and Negotiation." Teachers and Teaching: Theory and Practice 12(5): $527-47$.

Strom, R.D., \& Strom, P.S. (2002) Changing the rules: education for creative thinking. Journal of Creative Behaviour, 36, $183-200$.

Trent, J., \& DeCoursey. M. 2011. Crossing boundries and constructing identities: the experiences of early career mainland Chinese English language teachers in Hong Kong. Asia- Pacific Journal of Teacher Education. 39(1) 65- 78.

Van der Merwe, F., Van Wyk, M.M.Van Wyk, C. (2009). UFS Training Manual for the Pre-service Mentoship Programme. Unpublished. Bloemfontein: University of the FreeState.

Van Wyk,M.M. (2007). The Use of Cooperative Learning In Economics in the Further Education and Training Phase of the Free State Province. Ph.D Thesis, Unpublished. Bloemfontein: University of the FreeState.

Wang, W.C., \& Cheng, Y.Y. (2000). Development and item response analysis of the creativity development inventory. Annual Journal of Test, 47: $153-173$.

Weedon,C. (1997). Feminist practice and poststructuralist theory. Malden, UK: Blackwell.

Wenger, E. (1998). Identity in practice. Communities of practice: Learning, meaning and identity. New York. Cambridge University Press.

Wetherell, M., Taylor, S., \& Yates, S. (2001). Discourse theory and practice. London: Sage.

Zembylas, M. (2003). Emotions and teacher identity: a poststructural perspective, Teachers and Teaching: theory and Practice, 9(3): 213-238.

Zembylas, M. (2008). Interrogating 'Teacher identity': emotion, resistance and self-formation. Educational Theory, 58(1): 107-127. 